\title{
Effect of PHA and LPS on the Activity of Nonspecific Cytotoxic Cells and Macrophages of Rainbow Trout (Oncorhynchus mykiss)
}

\section{Efecto del PHA y LPS en la Actividad de las Células Citotóxicas Naturales y Macrófagos de Trucha Arcoíris (Oncorhynchus mykiss)}

\author{
Leonardo A. Gómez ${ }^{1}$, Raúl Cortés² \& Carlos T. Smith ${ }^{1,3 *}$ \\ ${ }^{1}$ Department of Microbiology, Faculty of Biological Sciences, University of Concepción, Concepción, Chile. \\ 2Department of Fish Physiology and Biotechnology, Instituto de Acuicultura de Torre de la Sal (IATS), Consejo Superior de \\ Investigaciones Científicas (CSIC), Castellón, Spain. \\ ${ }^{3}$ Department of Microbiology, Faculty of Biological Sciences, University of Concepción, Chile, Casilla 160-C, Concepción, \\ Chile. Telephone: 56 (41) 2204287, Fax: 56 (41) 2245975. \\ *E-mail: csmith@udec.cl
}

\begin{abstract}
This work studied the effect of the lectin phytohaemagglutinin (PHA) and bacterial lipopolysaccharide (LPS) on the activity of nonspecific cytotoxic cells (NCCs) and macrophages of peripheral blood in the rainbow trout. NCCs are cells of the innate immunity, homologues to Natural Killer (NK) cells of mammals, capable of eliminating cells infected with intracellular pathogens and also tumoral cells. Their lytic activity is mediated by the perforin/granzyme system and the Fas receptor-Fas ligand (FasR-FasL) system. Activity of NCCs was evaluated by their capacity to lyse HL-60 tumor cells. On the other hand, macrophages eliminate microorganisms by several mechanisms, including the production of reactive oxygen species (ROS) and nitric oxide (NO). Results showed that PHA significantly increased NCCs cytotoxic activity against HL-60 cells, even under conditions in which the perforins/granzymes lytic system should be suppressed, supporting the existence of the FasR-FasL system in trouts. PHA showed no effect on ROS and NO production by macrophages. Finally, LPS showed no effect on the cytotoxic activity of NCCs or in the production of ROS and NO by macrophages.
\end{abstract}

KeYwoRDs: Interleukins, innate immunity, FasR-FasL, lectins, leukocytes.

\section{RESUMEN}

En este trabajo evaluamos el efecto de la lectina fitohemaglutinina (PHA) y del lipopolisacárido bacteriano (LPS) sobre la actividad de las células citotóxicas naturales (NCCs) y de los macrófagos de la sangre periférica de la truchas arcoíris. Las NCCs son células de la inmunidad innata, homologas a las células Natural Killer (NK) de mamíferos, capaces de eliminar células infectadas con patógenos intracelulares y también células tumorales. Su actividad lítica es mediada por las perforinas/granzymas y el sistema Fas receptor-Fas Ligando (FasR-FasL). La actividad de estas células fue evaluada por su capacidad para lisar células tumorales HL-60. Por otro lado, los macrófagos eliminan microrganismos mediante diversos mecanismos, los que incluyen la producción de especies reactivas del oxígeno (ROS) y del óxido nítrico (NO). Nuestros resultados muestran que el PHA incrementa significativamente la actividad de las NCCs contra las células HL-60, aún bajo condiciones en las que el sistema lítico de las perforinas/granzimas estaría suprimido, apoyan la existencia del sistema FasR-FasL en truchas. El PHA no mostró efecto alguno en la producción de ROS y NO por los macrófagos. Finalmente, al evaluar el efecto del LPS en ambas poblaciones celulares, no se obtuvo efecto alguno tanto en la actividad citotóxica de las NCCs, como tampoco en la producción de ROS y NO por los macrófagos.

Palabras clave: Interleuquinas, inmunidad innata, FasR-FasL, lectinas, leucocitos. 


\section{INTRODUCTION}

Chile is one of the most important worldwide producers of salmonids and despite suffering difficult days it is showing signs of recovery (Eposito 2011) producing almost 650,000 metric tons in 2011 (Sernapesca 2011). In general, large productivity tends to be associated with high densities of animals, favoring dissemination of infectocontagious diseases. Furthermore, high densities increase stress in the animals, negatively affecting its defensive responses and increase the risk of spreading infections (Barton \& Iwama 1991). In order to challenge pathogenic microorganisms, just like the rest of vertebrates, fish posses innate (nonspecific) and adaptive (specific) immunological responses (Magnadóttir 2006; Tort et al. 2003). Both work coordinately and are essential in order to eliminate "foreignness" (antigens) by means of signals which, in vertebrates in general, are provided mainly by interleukins (Bird et al. 2006; Manning \& Nakanishi 1996). Innate immunity of fish has been extensively studied and reviewed (Whyte 2007; Magnadóttir 2006; Tort et al. 2003).

Innate immunity is the first line of defense against infectious diseases and it is composed by a number of elements including, among others, physico-chemical barriers and several types of cells and molecules protecting against foreignness (Magnadóttir 2006). Among the cellular components of fish innate immunity we can include cytotoxic cells, functionally homologous to natural killer cells (NK) of mammals, called nonspecific cytotoxic cells (NCCs) (Bishop et al. 2002; Ristow et al. 2000; Evans \& Jaso-Friedmann 1992). Since their main function is to eliminate cells infected with intracellular pathogens (bacteria and virus) and also tumor cells, lysing them or inducing them to undergo apoptosis, NCCs play an important role in fish immunity (Ellis 2001; Ristow et al. 2000; Hogan et al. 1996; Evans \& Jaso-Friedmann 1992). One of the mechanisms used by NCCs, referred as the "lethal hit", produces the lysis of infected or altered cells secreting perforins/granzymes contained in their cytoplasmic granules (Athanasopoulou et al. 2009; Praveen et al. 2006). Perforins polymerize in the membrane of target cells, depending on Calcium, producing a pore leading to the lysis of the target cell and granzymes, whose entry is facilitated by perforins, induce their apoptosis. A second cytotoxic mechanism, independent of Calcium, leading to the apoptosis of infected or altered cells is mediated by the Fas receptor-Fas ligand (FasR-FasL) system, involving the interaction of Fas-L (located in the membrane of cytotoxic cells) with the Fas-R (located in the membrane of target cells) (Kaur et al. 2004; Cuesta et al. 2003; Bishop et al. 2002) making target cells lacking FasR resistant to this mechanism. Using Calcium chelating agents, such as EGTA, it is possible to avoid perforins/granzymes mediated target cells lysis, making it possible to evaluate in vitro the activity of one or both of these mechanisms (Duke 2000).

Other important effectors of the fish innate response are macrophages, also present in all vertebrates. Macrophages are mononuclear phagocytic cells; they eliminate microorganisms by means of several mechanisms, including phagocytosis and the production of reactive oxygen species (ROS) and reactive nitrogen species (RNS) such as nitric oxide (NO). Both, ROS and NO are highly toxic compounds for phagocytosed microorganisms (Walsh et al. 2006; Lundén et al. 2002; Secombes 1996) allowing macrophages to destroy them.

In whole organisms, lytic mechanisms of NCCs and production of ROS and NO by macrophages are stimulated by pathogen associated molecular patters (PAMPs), numerous nutritional and immunostimulating agents (Sakai 1999). On the other hand, polyclonal activators, such as phytohaemagglutinin (PHA) and bacterial lipopolysaccharide (LPS), stimulate the immune response activating the same immunocompetent cells and signaling pathways activated by microorganisms. Therefore in vitro PHA and LPS activation studies allow to estimate the immune response of whole organisms against infection.

Although PHA and LPS are polyclonal activators of lymphocytes, immunocompetent cells of the adaptive immune response (Kurata et al. 2011; Sepulcre et al. 2007; Zou et al. 2005; Blohm et al. 2003), the activation of lymphocytes affect cells involved in innate immunity, such as NCCs and macrophages (Bird et al. 2006), cells assayed in this study. Thus, since PHA and LPS activated lymphocytes increase their activating signals for NCCs and macrophages, we are assuming that, in turn, these innate immunocompetent cells will respond increasing the lytic activity of NCCs and the production of ROS and NO by macrophages, which this study pretends to prove as its aim.

\section{MATERIAL AND METHODS}

ISOLATION AND CULTURE OF PERIPHERAL BLOOD MONONUCLEAR CELls (PBMC)

Peripheral blood was drawn from apparently healthy rainbow trouts (Oncorhynchus mykiss Walbaum, 1792) by caudal vein puncture using heparinized syringes at the fish farm "Salmones Pangue" (Bio Bio Region, Chile). Animals weight ranged from 180 to $210 \mathrm{~g}$. Blood samples were transported, at $4^{\circ} \mathrm{C}$, to the Immunology Laboratory, Department of Microbiology, Faculty of Biological Sciences, University of Concepción (Concepción, Chile). Blood samples arrived to the laboratory within $1 \mathrm{~h}$ after being drawn. 
NCCs and macrophages were obtained as peripheral blood mononuclear cells (PBMs), which include both cellular types, using standard methodology. Briefly, PBMs were collected as buffy coat after centrifuging the blood in ficoll-hypaque (density $1.077 \mathrm{~g} / \mathrm{ml}$ ) (Sigma Diagnostics, St. Louis., MO., USA) at $500 \mathrm{x}$ g for $30 \mathrm{~min}$ (Greenlee \& Ristow 1992). Cellular viability was assessed using $0.4 \%$ trypan blue (Sigma Chemical Co, St Louis MO, USA) and PBMCs were cultured at a concentration of $10^{6}$ viable cells/ $\mathrm{ml}$ in RPMI 1640 medium (Gibco BRL, Grand Island NY, USA) supplemented with $10 \%$ fetal calf serum (FCS), $100 \mathrm{IU} / \mathrm{ml}$ penicillin and $120 \mu \mathrm{g} / \mathrm{ml}$ streptomycin (Sigma Aldrich Inc, St. Louis, MO, USA) at $15^{\circ} \mathrm{C}$. PBMCs were stimulated with the lectin PHA or Escherichia coli 0111:B4 LPS (Sigma Chemical Co., St. Louis., MO., USA) at final doses of $10 \mu \mathrm{g} / \mathrm{ml}$ (Kurata et al. 2011; Sepulcre et al. 2007; Zou et al. 2005) and cultured at $15^{\circ} \mathrm{C}$. Controls lacked PHA and LPS. Cytotoxic activity of NCCs and production of ROS and NO by macrophages were evaluated after 1, 24 and $48 \mathrm{~h}$ of incubation. A total of 5 animals were sampled for each incubation period.

\section{ACTIVITY OF NONSPECIFIC CYTOTOXIC CELLS (NCCs)}

Activity of NCCs was evaluated at times 1, 24 and 48 $\mathrm{h}$ after PHA or LPS stimulation. Also, EGTA (Sigma Chemical Co., St. Louis., MO., USA) was used as chelant to discriminate the activity of perforins/granzymes dependant and FasR-FasL dependant cytotoxic mechanisms of NCCs (Companjen et al. 2006; Duke 2000). Cytotoxic activity was assessed by lysis of HL-60 cells (ATCC, Rockville, MD. USA) mediated by NCCs. HL-60 cells, having membrane bound FasR, are sensitive to both perforins/granzymes and FasR-FasL system cytotoxicities. Briefly, $100 \mu \mathrm{l}$ effector PBMCs $\left(1 \times 10^{6}\right.$ cells/ml in RPMI medium supplemented as described above) were co-incubated for $3 \mathrm{~h}$ with $1000 \mu \mathrm{l}$ HL-60 cells $\left(1 \times 10^{6}\right.$ cells $/ \mathrm{ml}$ in the same culture medium already described), in the presence or absence of $5 \mathrm{mM}$ EGTA (Duke 2000). Target cells were previously labeled for $30 \mathrm{~min}$ with neutral red $(0.036 \mathrm{w} / \mathrm{v})$ (Merck, Darmstadt, Germany) and washed three times. Cytotoxic activity was evaluated measuring neutral red released from lysed cells using a spectrophotometer at $540 \mathrm{~nm}$ (Parish \& Mullbacher 1983). Each sample from each fish was processed by triplicate.

\section{ACTIVITY OF MACROPHAGES}

Activity of these cells was evaluated by means of the production of ROS and NO. ROS were evaluated as described by Anderson \& Siwicki (1993) with modifications, at times 1, 24 and $48 \mathrm{~h}$ after stimulation with either PHA or LPS. Briefly, $100 \mu \mathrm{l}$ of culture containing $1 \times 10^{6}$ cells $/ \mathrm{ml}$ were incubated in Eppendorf tubes with $100 \mu \mathrm{l}$ of $0.1 \%$ nitroblue tetrazolium (NBT) (Sigma Chemical Co., St. Louis., MO.,
USA) for $1 \mathrm{~h}$. One $\mathrm{ml}$ of N,N-dimethylformamid (Merck, Darmstadt, Germany) was added to each Eppendorf tube and the mixture centrifuged for $10 \mathrm{~min}$ at $100 \mathrm{x} \mathrm{g}$. ROS were evaluated by their capacity to reduce NBT into the colored compound formazan, which was spectrophotometrically measured at $620 \mathrm{~nm}$. Assays were done in triplicate. The NO production was assessed at times 1, 24 and $48 \mathrm{~h}$ after stimulation with PHA or LPS using a procedure modified from Walsh et al. (2006) using Griess reagent (sulfanilamide, $\mathrm{N}$-naphthyl ethylenediamine and phosphoric acid) (SigmaAldrich Co., St. Louis., MO., USA). Briefly, $200 \mu$ l of cell culture $\left(1 \times 10^{6}\right.$ cells $\left./ \mathrm{ml}\right)$ was centrifuged for $10 \mathrm{~min}$ at 100 $\mathrm{x} g$ and $100 \mu \mathrm{l}$ of the supernatant was collected. Supernatant was incubated with $100 \mu \mathrm{l}$ of $1 \%$ sulfanilamide for $10 \mathrm{~min}$; later, $100 \mu \mathrm{l}$ of $0.1 \% \mathrm{~N}$-naphthyl ethylenediamine was added and incubated for $30 \mathrm{~min}$. Measurements were done spectrophotometrically at $540 \mathrm{~nm}$. Each sample from each fish was processed by triplicate.

\section{STATISTICAL ANALYSIS}

The effect of PHA and LPS on the lytic mechanism of NCCs and on ROS and NO production by macrophages was analyzed by a one-way ANOVA and Tukey's test. Differences were considered significant if $p<0.05$.

\section{RESULTS}

\section{Cytotoxic activity of NCCs}

After $24 \mathrm{~h}$ of incubation of PBMCs with PHA, cytotoxic activity by NCCs over HL-60 targets increased but it was not statistically significant (Fig. 1). After 48 h, cytotoxic activity was significantly increased when compared to control (Fig. 1). In the presence of $5 \mathrm{mM}$ EGTA, the statistically significant cytotoxic activity increase appeared after $24 \mathrm{~h}$ and was still present at $48 \mathrm{~h}$ (Fig. 2). On the other hand, incubation of PBMCs with LPS had no effect on NCCs cytotoxic activity in the absence or presence of EGTA (Fig. 1 and 2, respectively).

\section{Production of ROS AND NO by macrophages}

Macrophages activity of rainbow trout peripheral blood was evaluated by the production of ROS and NO after stimulation with PHA and LPS $(10 \mu \mathrm{g} / \mathrm{ml})$. ROS and NO activities were evaluated after 1, 24 and $48 \mathrm{~h}$ of stimulation. Results showed that, when comparing the experimental groups with the control of their respective time, neither PHA nor LPS significantly affected ROS or NO production by macrophages (Fig. 3 and 4). It is worth mentioning that NO production at times 24 and 48 hours decreased if compared with the time 1 hour, but since both, controls and experimental groups decreased alike we can consider that it was not caused by the treatment with PHA or LPS. 


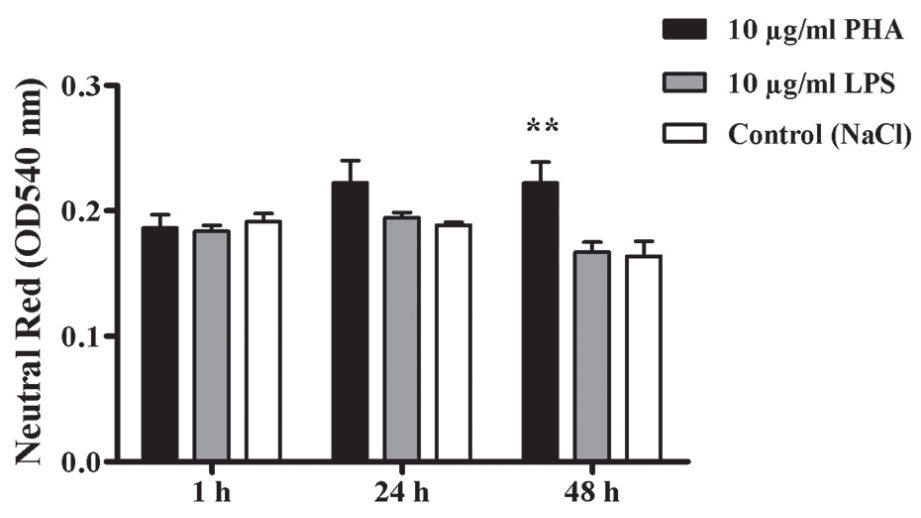

FIGURE 1. PHA and LPS effect on the cytotoxic activity by NCCs. Cytotoxicity was evaluated by release of neutral red from lysed HL-60 target cells. $\mathrm{n}=5$ and bar indicates standard deviation. Statistical differences: $* *(p<0.01)$.

Figura 1. Efecto del PHA y LPS sobre la actividad citotóxica de las NCC. La citotoxicidad fue medida por la liberación del rojo neutro desde las células HL-60 lisadas. $\mathrm{n}=5$ y las barras representan la desviación estándar. Diferencias significativas: $* *(p<0,01)$.

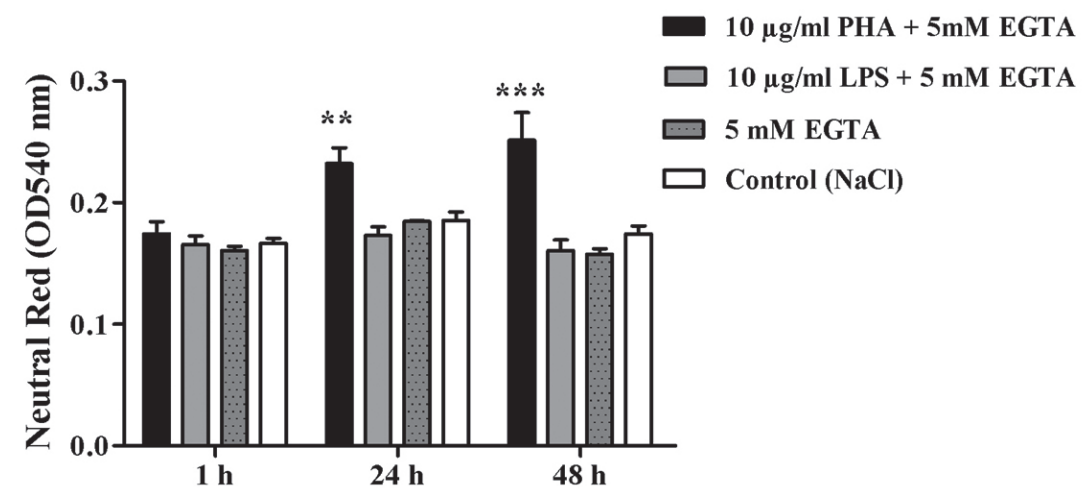

FIGURE 2. PHA and LPS effect on the cytotoxic activity by NCCs in the presence of $5 \mathrm{mM}$ EGTA. Cytotoxicity was evaluated by release of neutral red from lysed HL-60 target cells. $\mathrm{n}=5$ and bar indicates standard deviation. Statistical differences: $* *(p<0.01)$ and $* * *(p<$ $0.001)$

FIGURA 2. Efecto del PHA y LPS en la actividad citotóxica de las NCC en presencia de 5 mM EGTA. La citotoxicidad fue evaluada por la liberación del rojo neutro desde las células HL-60 lisadas. $\mathrm{n}=5 \mathrm{y}$ las barras representan la desviación estándar. Diferencias significativas: $* *(p<0,01) \mathrm{y} * * *(p<0,001)$.

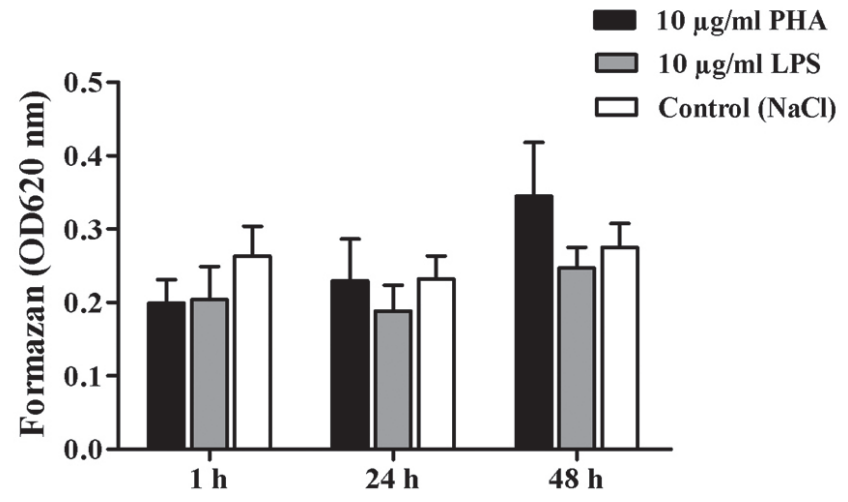

FIGURE 3. PHA and LPS effect on the production of reactive oxygen species (ROS), measured at times 1,24 and $48 \mathrm{~h}$. $\mathrm{n}=5$ and bar indicates standard deviation.

FiguRA 3. Efecto del PHA y LPS en la producción de especies reactivas del oxígeno (ROS), medidas a los tiempos 1,24 y $48 \mathrm{~h}$. $\mathrm{n}=5 \mathrm{y}$ las barras representan la desviación estándar. 


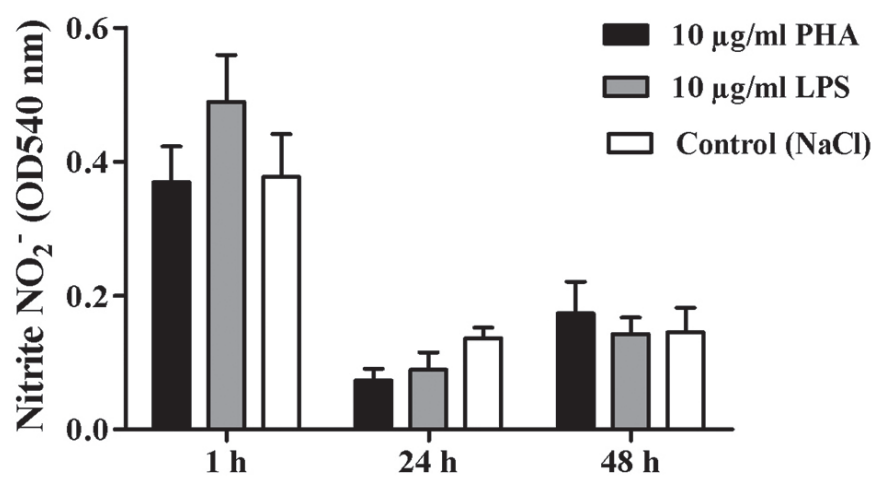

Figure 4. PHA and LPS effect on the production of nitric oxide measured as nitrite $\left(\mathrm{NO}_{2}^{-}\right)$, at times 1,24 and $48 \mathrm{~h} . \mathrm{n}=5$ and bar indicates standard deviation.

Figura 4. Efecto del PHA y LPS en la producción de óxido nítrico medido como nitrito $\left(\mathrm{NO}_{2}^{-}\right)$, a los tiempos 1,24 y $48 \mathrm{~h}$. n $=5$ y las barras representan la desviación estándar.

\section{DISCUSSION AND CONCLUSIONS}

Traditionally, a series of compounds have been used in order to activate or inhibit cells associated with the immune response (Sakai 1999). PHA and LPS have been described as polyclonal activators of T and B lymphocytes, respectively (Kurata et al. 2011; Sepulcre et al. 2007; Zou et al. 2005; Blohm et al. 2003) and that their in vitro activation correlates to their in vivo effect in whole organisms (Campbell \& Colonna 2000). This correlation is what gives value to the in vitro experiments.

Our in vitro results indicate that the cytotoxic activity by NCCs is increased by PHA in the absence as well as in the presence of EGTA (Fig. 1 and 2), chelator used to inhibit the lytic activity mediated by perforins/granzymes because it depends on extracellular $\mathrm{Ca}^{++}$availability (Companjen et al. 2006; Duke 2000). Although Fig. 1 shows that PHA did not significantly increased cytotoxic activity by NCCs after $24 \mathrm{~h}$, the increase in activity is apparent, becoming significant at the next sampling time. Considering that the cytotoxic activity increase is maintained in the presence of EGTA (condition in which perforins/granzymes should not be operative) and since HL-60 cells have FasR and therefore are targets to lysis by the FasL-FasR system (Bishop et al. 2002), our result support the presence of the FasR-FasL system in salmonids but additional immunological and molecular studies are required to confirm it. This result agrees with that reported by Kurata et al. (2011) showing that $10 \mu \mathrm{g} / \mathrm{ml}$ of PHA significantly increased FasL transcription in the Japanese flounder (Paralichthys olivaceus). Since citotoxicity by NCCs was similar in the presence and in the absence of EGTA, it can be also concluded that the activity of one of them (FasL-FasR) is sufficient to achieve target cell lysis. Although FasL is not only present in NCCs but also in T lymphocytes, since PBMC-HL60 cells were co-incubated for only $3 \mathrm{~h}$, T cells of the adaptive immune response present in the PBMCs would not be able to lyse HL-60 target cells given such a short time period. Therefore, the lysis of target HL-60 cells in this work can be attributed only to the innate response (NCCs).

In mammals, NK cells (equivalent to fish NCCs) are stimulated by certain interleukins (ILs) produced by $\mathrm{T}$ lymphocytes, demonstrating that mammalian lymphocytes can regulate the activity of cells involved in innate immunity. Since findings on mammalian immunity, main focus of immunological research, are usually later on confirmed in the rest of the vertebrates, it is possible to assume that fish lymphocytes can regulate NCCs and macrophages because they posses IL-2 and other interleukins (Bird et al. 2006; Manning \& Nakanishi 1996). Thus, since fish $T$ lymphocytes produce IL-2 and it has been reported that IL-2 increases fish natural cytotoxic activity (Bird et al. 2006), PHA effect on NCCs might be mediated by IL-2.

LPS, at a concentration of $10 \mu \mathrm{g} / \mathrm{ml}$ for up to $48 \mathrm{~h}$, had no effect on NCCs activity (Fig. 1 and 2). Since LPS is known as a $\mathrm{B}$ lymphocytes polyclonal activator, it was less likely to expect effects on NCCs.

On the other hand, up to $48 \mathrm{~h}$ stimulation with $10 \mu \mathrm{g} / \mathrm{ml}$ of PHA or LPS had no effect on ROS and NO activities (Fig. 3 and 4). Although PHA is a T lymphocyte polyclonal activator, an increase of ROS or NO production by macrophages could have been consequence of T lymphocyte modulation on macrophages, but it was not observed up to after $48 \mathrm{~h}$ of PBMCs stimulation. It was reasonable 
to consider that LPS could have increased ROS and NO activity in macrophages acting as a pathogen associated molecular pattern (PAMP), an effect not observed in this work. Sepulcre et al. (2007) showed that $10 \mu \mathrm{g} / \mathrm{ml}$ LPS act as a PAMP increasing phagocytosis by gilthead seabream (Sparus aurata) granulocytes, a cell population not included in the PBMCs. Perhaps $10 \mu \mathrm{g} / \mathrm{ml}$ LPS might stimulate macrophages activity if used jointly with other activators, such as the macrophage activating factor, as proposed by Secombes (1996).

Thus, our results in the rainbow trout showed, as expected, that PHA increases NCCs cytotoxic activity, enhancing protection against challenge from intracellular pathogens and tumor cells. Several infections affecting salmonids are caused by intracellular pathogens, either bacterial, such as Piscirickettsia salmonis and Renibacterium salmoninarum (Fryer \& Hedrick 2003; Daly et al. 2001) or viral, such as infectious pancreatic necrosis virus (IPNv), viral hemorrhagic septicemia virus (VHSv) and infectious salmon anemia virus (ISAv) (Crane \& Hyatt 2011). Some of these microorganisms have caused serious losses to the Chilean aquaculture industry (Asche et al 2010) and NCCs are the key innate immunity responders against them. Therefore, an enhanced activity of NCCs, such as the one provided by PHA, will improve the capacity of the fish to challenge this type of microorganisms. In the particular case of bacteria, this may reduce the use of antibiotics, decreasing the selective pressure leading to the emergence of multiresistant bacteria. With respect to LPS, despite being a PAMP, it did not show any effect on the innate response parameters studied in this work.

\section{ACKNOWLEDGEMENTS}

This work was partially supported by Grant 97.036.051, Universidad de Concepción. We thank Mr. Ricardo Quiroz (Salmones Pangue), who allowed us to perform the experiments at the pisciculture premises. We are grateful to Dra. Coralia Rivas, Department of Physiopathology, Faculty of Biological Sciences, University of Concepción, Chile, who provided us the HL-60 cells.

\section{REFERENCES}

Anderson, D. \& Siwicki, A. 1993. Measuring the effects of contaminants on fish by haematological and serological methods. In: Modulators of fish immune responses (Eds. Stolen, J., D. Anderson, S. Zelikoff, L. Twerdok \& S. Kaattari), pp 95-118. SOS Publications, Fair Haven NJ.

Asche, F., Hansen, H., \& Tveteras, R.C. 2010. The salmon disease crisis in Chile. Marine Resource Economics 24: 405-411.

Athanasopoulou, S., Marioli, D., Mikrou, A., Papanastasiou,
A., ZARKADIS, I. 2009. Cloning and characterization of the trout perforin. Fish \& Shellfish Immunology 26: 908-912.

Barton, B. \& Iwama, G. 1991. Physiological changes in fish from stress in aquaculture with emphasis on response and effects of corticosteroids. Annual Review of Fish Diseases, pp. 3-26.

Bird, S., Zou, J. \& Secombes, C. 2006. Advances in fish cytokine biology give clues to the evolution of a complex network. Current Pharmaceutical Design 12: 3051-3069.

Bishop, G., Taylor, S., Jaso-Friedmann L. \& Evans, D. 2002. Mechanisms of nonspecific cytotoxic cell regulation of apoptosis: cytokine-like activity of Fas ligand. Fish \& Shellfish Immunology 13: 47-67.

Blohm, U., Siegl, E. \& Köllner B. 2003. Rainbow trout (Oncorhynchus mykiss) sIgM leukocytes secrete an interleukin-2 like growth factor after mitogenic stimulation in vitro. Fish \& Shellfish Immunology 14: 449-466.

Campbell, K. \& Colonna, M. 2000. Natural killer cell protocols. In: Cellular and molecular methods, methods in molecular biology series, Vol. 121, Humana Press Inc., Totowa, NJ.

Companjen, A., Heinhuis, B., Aspers, K. \& Rombout, J. 2006. In vivo evoked specific cell mediated cytotoxicity in carp (Cyprinus carpio L.) uses mainly a perforin/granzyme-like pathway Fish \& Shellfish Immunology 20: 113-117.

Crane, M. \& Hyatt, A. 2011. Viruses of fish: An overview of significant pathogens. Viruses 3: 2025-2046.

Cuesta, A., Esteban, M. \& Meseguer, J. 2003. Identification of a FasL-like molecule in leucocytes of the teleost fish gilthead seabream (Sparus aurata L.). Developmental \& Comparative Immunology 27: 21-27.

Daly, J., Griffiths, S., Kew, A., Moore, A. \& Olivier, G. 2001. Characterization of attenuated Renibacterium salmoninarum strains and their use as live vaccines. Disease of Aquatic Organisms 44: 121-126.

Duke, R. 2000. Methods of analyzing chromatin changes accompanying apoptosis of target cells in killer cell assays. In: Natural killer cell. Protocols cellular and molecular methods (Ed. by Campbell, K. \& Colonna, M.) Humana Press Inc., Totowa, NJ. pp 125-143.

Ellis, A. 2001. Innate host defense mechanism of fish against viruses and bacteria. Developmental \& Comparative Immunology 25: 827-839.

Eposito, A. 2011. Chile's salmon industry on pace for record sales. URL: http://www.marketwatch.com/story/chiles-salmonindustry-on-pace-for-record-sales Accessed October 4, 2011.

Evans, D. \& Jaso-Friedmann, L. 1992. Nonspecific cytotoxic cell as effectors of immunity in fish. Annual Reviews of Fish Diseases 2: 109-121.

Fryer, J. \& Hedrick, R. 2003. Piscirickettsia salmonis: a Gramnegative intracellular bacterial pathogen of fish. Journal of Fish Disease 26: 251-262.

Greenlee, A. \& Ristow, S. 1992. Detection of apoptic killing by trout nonspecific cytotoxic cell using the DNA fragmentation assay and agarose gel electrophoresis. In: Techniques in fish immunology Vol. 2 (Eds. Stolen, J., Fletcher, T., Anderson, D., Kaattari, S. \& Rowley, R.), pp 97-105. SOS Publications, Fair Haven NJ.

Hogan, R., Stuge, T., Clem, L., Miller, N., \& Chinchar, V. 1996. Anti-viral cytotoxic cells in the channel catfish (lctalurus 
punctatus). Developmental \& Comparative Immunology 20: 115-127.

Kaur, H., Jaso-Friedmann, L. \& Evans, D. 2004. Single base oligodeoxyguanosine upregulates Fas ligand release by nonspecific cytotoxic cells. Developmental \& Comparative Immunology 28: 571-579.

Kurata, O., Iwasaki, T., Matsuyama, T., Nakayasu, C., Wada, S. \& HataI, K. 2011. Lymphocytes with T-cell-like properties express the Fas ligand in the Japanese flounder Paralichthys olivaceus. Fish \& Shellfish Immunology 30: 509-514.

LundÉn, T., LiLIus, E. \& BYLund, G. 2002. Respiratory burst activity of rainbow trout (Oncorhynchus mykiss) phagocytes is modulates by antimicrobial drugs. Aquaculture 207: 203213.

MagnadótTiR, B. 2006. Innate immunity of fish (overview). Fish \& Shellfish Immunology 20: 137-151.

Manning, M. \& Nakanishi, T. 1996. The specific immune system: Cellular defenses. In: The fish immune system: organism, pathogen and environment (Eds. Iwama, G. \& T. Nakanishi), pp. 159-205. Academic Press Ltd., London.

PARISH, C. \& Müllbacher, A. 1983. Automated colorimetric assay for $\mathrm{T}$ cell cytotoxicity. Journal of Immunological Methods 58: 225-237.

Praveen, K., Leary, J., Evans, D. \& Jaso-Friedmann, L. 2006. Nonspecific cytotoxic cells of teleosts are armed with multiple granzymes and other components of the granule exocytosis pathway. Molecular Immunology 43: 11521162.

Ristow, S., Evans, D. \& Jaso-Friedmann, L. 2000. Analyzing nonspecific cytotoxic cells in fish. In: Natural killer cell. Protocols cellular and molecular methods (Eds. Campbell,
K. \& M. Colonna), pp. 347-357. Humana Press Inc., Totowa, NJ.

SAKAI, M. 1999. Current research status of fish immunostimulants. Aquaculture 172: 63-92.

Secombes, C. 1996. The nonspecific immune system: cellular defences. In: The fish immune system: organism, pathogen and environment (Eds. Iwama, G. \& T. Nakanishi), pp. 63103. Academic Press Ltd., London.

Sepulcre, M., López-Castejón, G., Meseguer, J. \& Mulero, V. 2007. The activation of gilthead seabream professional phagocytes by different PAMPs underlines the behavioural diversity of the main innate immune cells of bony fish. Molecular Immunology 44: 2009-2016.

SERnAPESCA. 2011. Anuario estadístico de pesca 2011.URL: http:// www.sernapesca.cl Accessed May 30, 2013.

Tort, L., Balasch, J. \& Mackenzie, S. 2003. Fish immune system. A crossroads between innate and adaptive responses. Inmunología 22: 277-286.

Walsh, C., Toranto, J., Gilliland, T., Noyes, D., Bodine, A. \& LuER, C. 2006. Nitric oxide production by nurse shark (Ginglymostoma cirratum) and clearnose skate (Raja eglanteria) peripheral blood leucocytes. Fish \& Shellfish Immunology 20: 40-46.

Whyte, S. 2007. The innate immune response of finfish- A review of current knowledge. Fish \& Shellfish Immunology 23: 1127-1151.

Zou, J., Carrington, A., Collet, B., MartinusJ., Yoshiura, Y., Bols, N. \& Secombes, C. 2005. Identification and bioactivities of IFN-g in rainbow trout Oncorhynchus mykiss: The first Th1-type cytokine characterized functionally in fish. Journal of Immunology 175: 24842494.

Recibido: 12.12 .2012

Aceptado: 10.06 .2013 